\title{
ÖNKÉNTES VÉRADÁS MAGYARORSZÁGON A COVID-19 VILÁGJÁRVÁNY IDEJÉN - A SZOCIODEMOGRÁFIAI HÁTTÉR, A PROSZOCIALITÁS ÉS AZ ÉSZLELT AKADÁLYOK ÖSSZEFÜGGÉSEINEK FELTÁRÓ VIZSGÁLATA
}

DORNER LÁSZLÓ ${ }^{1}$ - CSORDÁS GEORGINA²

DOI: https://doi.org/10.53585/OnkSzem.2022.1.3-22

\section{Absztrakt}

Az önkéntes véradás egy olyan proszociális magatartásforma, mely minden ország egészségügyi rendszerének alapkövét jelenti. Tanulmányunk célja annak bemutatása, milyen értelemben tekinthető önkéntességnek a véradás, valamint megvizsgálni a szociodemográfiai tényezők, a véradók általános proszociális aktivitása, a COVID járvány kapcsán észlelt akadályok és a betegségben való konkrét érintettség, valamint a pandémia alatti véradás gyakoriságának összefüggéseit. Továbbá célunk volt a motivációs háttérváltozók (morális felháborodás és vonakodó altruizmus) mérésére szolgáló skálák pszichometriai jellemzőinek vizsgálata hazai mintán, valamint azok proszociális aktivitással való összefüggéseinek feltárása is. Kutatásunk egy demográfiai (17 megye), életkori (18-68 év között, $M=$ $43,51 ; S D=11,98)$, valamint a véradások száma szempontjából egyaránt heterogén mintán ( $N=219)$ zajlott, online és papír alapú önkitöltő kérdőíves adatfelvétellel. Eredményeink arra mutatnak rá, hogy a véradók jelentős része a donáción kívül is folytat karitatív tevékenységet, fóként a pénzadományozás, valamint az önkéntes aktivitások gyakorisága emelkedik ki. A COVID alatti véradások száma negatív összefüggést mutat az attól való félelemmel, hogy a véradás helyszínén megfertőződik a vírussal, az azzal való egyetértéssel, hogy a pandémia alatti bezártság akadályt jelent a véradásban, valamint, kevés tudásunk van még a vírusról ahhoz, hogy biztonságosnak érezze a véradást. A közepes súlyosságú COVID érintettség jelentősen csökkentette a véradás gyakoriságát az enyhébb tünetekkel átesett személyekhez képest. Arra is rámutattunk, hogy a Morális Felháborodás és Vonakodó Altruizmus Skálák hazai véradó mintán történő alkalmazása ígéretes, előbbi a véradók többségénél magas, utóbbi közepes erősségú motivációs változóként azonosítható a skálákon kapott pontszámok alapján. Eredményeink alapján indokoltnak tartjuk más önkéntes mintákon is megvizsgálni ezen mérőeszközök validitását. A két konstruktum nem mutat összefüggést sem az eddigi összes, sem a COVID alatti véradások számával. Ezen összefüggések okainak feltárására további vizsgálatokat tervezünk a jövőben.

\footnotetext{
${ }^{1}$ Dorner László (PhD) pszichológus, egyetemi adjunktus, Eszterházy Károly Katolikus Egyetem, Pszichológia Intézet ${ }^{2}$ Csordás Georgina, pszichológus, egyetemi tanársegéd, Eszterházy Károly Katolikus Egyetem, Pszichológia Intézet
} 
Kulcsszavak: önkéntes véradás, COVID-19 járvány, akadályok, morális felháborodás, vonakodó altruizmus

\section{Voluntary blood donation in Hungary during the covid-19 pandemic - Exploratory}

\section{study on the connections between sociodemographic variables, prosocial}

\section{background, and perceived barriers}

\section{László Dorner - Georgina Csordás}

\section{Abstract}

Voluntary blood donation is a form of prosocial behaviour which is a cornerstone of every country's health system. The aim of our study is to investigate why blood donation is considered as a volunteer activity and to explore the connections between sociodemographic factors, general prosocial activity, perceived barriers, personal COVID exposure, and the number of blood donations during the COVID-19 pandemic. Furthermore, we investigated psychometric properties of the scales developed to measure motivational background variables (moral outrage and reluctant altruism) in a Hungarian sample and their connection with prosocial activity. Our study was conducted on a sample $(N=219)$ that was heterogeneous in terms of demographics (17 counties), age (between 18-68 years, $M=43.51 ; \mathrm{SD}=$ 11.98), and number of donations, and we used a mixed survey method (online and paper and pencil self-report survey) for data collection. Our results indicate that a significant proportion of blood donors engage in charitable activities besides blood donation, with monetary donations and volunteer activities being particularly prominent. The number of blood donations during the COVID-19 pandemic negatively correlates with fear of contracting the virus at the donation site, with acknowledgement that confinement during the pandemic hinders donations, and that insufficient knowledge about the virus reduces the feeling of security to donate blood. Experiencing moderate-severity COVID symptoms significantly reduced the frequency of blood donations compared to those with milder symptoms. We also point out that applying the Moral Outrage and Reluctant Altruism Scales to a domestic sample of blood donors is promising; based on the scores obtained on the scales, the former construct is identified as a higher and the latter as a medium-effect motivational factor. Further testing of the validity of these measures on other volunteer samples is recommended. The two constructs do not show significant connection with the total number of blood donations or with the number of donations during the COVID-19 pandemic. We intend to further explore the reasons for these associations.

Keywords: voluntary blood donation, COVID-19 pandemic, barriers, moral outrage, reluctant altruism 


\section{BEVEZETÉS}

Az önkéntes véradás az egyik legalapvetőbb humán segítségnyújtó aktivitás. ${ }^{3}$ A világon évente körülbelül 304 millió egység ${ }^{4}$, hazánkban pedig közel 390 ezer egység ${ }^{5}$ vérre van szükség a biztonságos vérellátás ${ }^{6}$ biztosításához. Korábbi vizsgálatok (Shan - Zhang 2004; Zeger et al 2007) rámutattak, hogy különleges történelmi helyzetekben megnőhet (lásd például a 2001. szeptember 11-i merényletet), de akár csökkenhet is (világjárványok) a véradási hajlandóság. Érdekesség, hogy a romániai forradalom idején 1989-ben jelentős számú véradó jelentkezett véradásra az Országos Vérellátó Szolgálatnál, a továbbiakban (OVSz). Amennyiben nincs elegendő vér, a kórházak nem tudják elvégezni a szükséges mútéteket, ellátni a vérkészítményre szoruló betegeket. Hazánkban azért is fontos a kérdés vizsgálata, mert bár stabil és zavartalan a vérellátás, annak fennmaradása a közösség minden tagjának fontos. $A$ tanulmányunk arra irányul, hogy bemutassa, hogyan alakul a COVID-19 világjárvány idején a véradás helyzete hazánkban, különös tekintettel arra, hogy milyen proszociális aktivitással rendelkeznek a véradók, és hogy a COVID-19 vírussal való érintettség milyen befolyással van erre.

Tanulmányunk áttekinti az önkéntes véradás fogalmi kérdéseit (proszociális és altruisztikus jelleg), a viselkedésforma hátterében fellelhető motivációs háttérváltozók (morális felháborodás és vonakodó altruizmus) és a szociodemográfiai háttér szerepét, majd az önkéntes véradás pandémia alatti helyzetét. Empirikus vizsgálatunkban a véradók általános proszociális, és a válsághelyzetben megnyilvánuló specifikus véradó aktivitásának, valamint COVID-19 érintettségének és az azzal összefüggő akadályok hatásainak összefüggésrendszerét vesszük górcső alá, majd pedig a fent említett motivációs háttérváltozók mérésére kidolgozott skálák megbízhatósági vizsgálatainak és proszociális változókkal való kapcsolatainak ismertetése kerül bemutatásra, végül pedig megvonjuk a konklúziókat a jelenlegi vírushelyzet hatását, jellegzetességeit illetően.

\footnotetext{
${ }^{3}$ Mi lehetne önzetlenebb cselekedet, mint a vérünket adni egy rászoruló idegennek? Ez egy „páratlan ajándék”, mondja Healy (2006:84). A vér nélkülözhetetlen a rászoruló betegek gyógyításában, az életmentésben. A tudomány mai állása szerint a vér mesterségesen nem előállítható, „a vér csak véradással pótolható” (az OVSz szlogenje 2022-ben, ovsz.hu)

${ }^{4}$ Roberts et al. 2019.

${ }^{5}$ https://www.ovsz.hu/hu/miert-fontos-veradas

${ }^{6}$ Vérátömlesztésre (transzfúzióra) elsősorban a nagy vérveszteséggel járó balesetek sérültjeinek ellátásakor, mútétek során van szükség, ill. számos súlyos betegség, mint a vérképzőszervi vagy rosszindulatú betegségek kezelése során a betegnek folyamatosan vérkészítményeket kell kapnia (ovsz.hu)
} 


\section{AZ ÖNKÉNTES VÉRADÁS MINT PROSZOCIÁLIS AKTIVITÁS}

A véradás alapvetően magas küszöbű proszociális (más személyek vagy csoportok jóllétének növelése érdekében végrehajtott) viselkedésforma, hiszen nem mindenki tud vagy szeretne vért adni, aki biológiai értelemben alkalmas arra, vagyis egy körülhatárolt véradó közösség tartja fenn a vérellátás zavartalan múködését, ami ugyanakkor az egész társadalom érdeke. Fontos megjegyeznünk, hogy bár a véradás alapvetően adományozási tevékenység, és hivatalosan nem tartozik a közérdekű önkéntes tevékenységek hatálya alá7, mégis az önkéntesség számos definíciós eleme megfigyelhető a jelenség kapcsán ${ }^{8}$. A 3/2005 EüM rendelet $^{9}$ szerint a vér önkéntes donoroktól térítésmentesen kerül levételre. Több kutatást idézve Alfieri et al. (2017) azt állítják, a véradás azért önkéntes tevékenység, mert a donor ahelyett, hogy idejéből áldozna, „magából ad”, testének egy számára is fontos elemét ajánlva fel egy idegen személynek, illetve, hogy a véradást koordináló szervezet számára egyéb, kifejezetten önkéntes aktivitásokat is végezhet a donor (pl. véradásszervezés, elsősegély, ételosztás). Ennek megfelelően az önkéntesség, civil tagságok és egyéb proszociális aktivitások meglehetősen gyakoriak a véradóknál (Alessandrini 2007; Alfieri et al. 2017).

\section{AZ ÖNKÉNTES VÉRADÁS MOTIVÁCIÓS HÁTTÉRVÁLTOZÓINAK VIZSGÁLATA}

\section{Tisztán altruista cselekedet-e a véradás?}

$A z$ önkéntes véradás viselkedéses értelemben altruisztikus, mivel a donor számára magas költségekkel jár: idejét, vérmennyiségének kb. 8-9 százalékát adományozza egy számára ismeretlen recipiensnek, aki mindezt nem viszonozza (Ferguson 2022; Lyle et al. 2009; Steinberg 2010).

Bár Titmuss (1970:46) a véradást „az altruista viselkedések legtisztább példájának” tekintette, mára pszichológiai értelemben nagyon ritkán tekintjük tisztán altruisztikusnak: a donor számára örömérzettel jár (úgynevezett warm glow), javíthatja társas kapcsolatait, hangsúlyozza a személy nagylelkűségét, költséges jelzés a társai számára az egészségéről stb.,

\footnotetext{
7 2005. évi LXXXVIII. törvény a közérdekű önkéntes tevékenységről

${ }^{8}$ Saját elhatározáson alapul, hivatalos keretek között végzik háztartásukon kívül élő személyek javára vagy a társadalom hasznára, gyakran hosszabb időn át történik (többszörös véradás), és nem jár érte anyagi ellenszolgáltatás, valamint a donor nem vár viszonzást cselekedetéért.

${ }^{9}$ https://net.jogtar.hu/jogszabaly?docid=a0500003.eum
} 
vagyis a vegyes motivációs bázis és a nem tiszta altruizmus terminusok általában pontosabban leírják a véradók (lásd. Ferguson 2015; Ferguson 2022), valamint az önkéntes tevékenységeket végzők (Carpenter - Myers, 2010) motivációs hátterét is. Ennek kapcsán érdemes górcső alá vennünk a proszocialitás egyes kurrens magyarázó elméleteit.

\section{A morális felháborodás}

Az első jelentős háttérváltozó, amelyet érdemes megvizsgálnunk, a morális felháborodás kérdésköre. Ez az érzelem akkor válik motivációs hajtóerővé, amikor a személy úgy észleli, más emberekkel szemben méltánytalanul vagy igazságtalanul járnak el, aminek hatására megfigyelőként negatív érzelmi folyamatokat (például dühöt) él át (Montada - Schneider 1989; van Doorn et al. 2014). A negatív érzések feloldására kiválóan alkalmas a proszociális viselkedés (Montada - Schneider 1989). A morális felháborodás ugyanis arra sarkallja a személyt, hogy proszociális cselekedeteivel pozitív hatást gyakoroljon a környezetére, részben, hogy fenntartsa pozitív énképét, részben, hogy a társas csoportját vagy a társadalmat jobb irányba terelhesse (Lotz et al. 2011; Thulin - Bicchieri 2016; van de Vyver-Abrams 2015). A jelenség a kollektív cselekvés számos formája, így a politikai aktivizmus és az önkéntesség hátterében is kimutatható (Csaba et al. 2017). A véradás kontextusában ez a jelenség akkor válhat motiváló tényezővé, amikor a véradó méltánytalannak érzi, hogy egy kis közösség (véradók) adományát az egész populáció (például ország) használja, és aggódik amiatt, hogy nem lesz elég vér, amely számára fontos morális értékeit és normáit (például a csoport segítése, viszonosság, méltányosság) veszélyezteti. Vagyis a morális felháborodás generálta cselekvés csökkenti a személy helyzet miatt érzett stresszállapotát.

\section{A vonakodó altruizmus}

A vonakodó altruizmus az utóbbi évtizedek segítségnyújtással kapcsolatos kutatásaiban (Evans - Ferguson 2014; Ferguson et al. 2012; Ferguson 2015; Ferguson - Lawrence 2018) ugyancsak egyre gyakrabban jelenik meg a „nem tiszta altruizmus” fontos elemeként: a vonakodó altruisták nem bíznak abban, hogy mások segíteni fognak, mások „potyázása” (megtehetnék, hogy segítsenek, de nem teszik), cselekvésre (segítségnyújtásra) sarkallja őket. Ennek hátterében a segítségben való bizalom hiánya és a potyautasok iránti negatív érzelmekpéldául harag - egyaránt kimutathatóak. Továbbá annak az érzése is ide tartozik, hogy a társas normák egy másokkal nem törődő társadalmat tükröznek. Ez különösen igaz egy olyan jelenség kapcsán, mint a véradás, ahol a véradásra jogosult lakosság 4 százalékának 
nagylelkűségére támaszkodik a társadalom maradék 96 százaléka (hiszen bármikor szorulhatnak vérkészítményre). Ferguson et al. (2012) például az új véradóknál (1-4-szeres) kifejezetten hangsúlyos motivációs tényezőként azonosították a vonakodó altruizmust. A vonakodó altruizmus tehát azt feltételezi, hogy az ilyen motivációjú véradók nagyobb valószínűséggel adnak vért akkor, ha úgy látják, hogy mások nem segítenek, amikor pedig megtehetnék, vagy tisztességtelenül cselekszenek. Ezzel összhangban a véradókról már viselkedéses közgazdaságtani keretben is kimutatták, hogy fokozottan hajlamosak büntetni a másokkal való méltánytalan bánásmódot (Ferguson - Lawrence 2018).

\section{AZ ÖNKÉNTES VÉRADÁS SZOCIODEMOGRÁFIAI HÁTTERE}

Az önkéntes véradás gyakoriságára a demográfiai tényezők is hatást gyakorolnak (BélaCsovcsics - Kincsesné Vajda, 2018). Az önkéntes véradás 18 és 65 éves kor között lehetséges, azonban mind a nemzetközi (Alessandrini 2007; Piersma 2017), mind a hazai eredmények (Nagy 2022) arra mutatnak rá, hogy a véradók átlagéletkora egyre nő és az idősebbek nagyobb arányban és gyakrabban is adnak vért ${ }^{10}$, így a fiatalabb korosztályok és a néhányszoros véradók hatékony megszólítása növekvő jelentőségű ${ }^{11}$. Azt is fontos kiemelnünk, hogy a család és a tágabb társas közeg (baráti és munkakapcsolatok) jelentős szerepet játszanak a véradó aktivitásban (Alessandrini 2007). Ugyancsak fontos, hogy lássuk: a véradás nem csak egy egyszeri esemény, hanem egy véradói életút része, ami alapján megkülönböztethetünk új és néhányszoros donorokat, lojális (sokszoros) véradókat, lemorzsolódott és jelenleg nem aktív donorokat egyaránt (Dorner 2020). Piersma et al. (2017) szisztematikus áttekintő tanulmányukban arra a következtetésre jutottak, hogy országonkénti eltérést mutat, hogy a nők vagy a férfiak lesznek-e nagyobb eséllyel véradók. Ugyanakkor azt találták, hogy férfiak nagyobb eséllyel válnak sokszoros véradóvá (>10), és általában gyakrabban is adnak vért ${ }^{12}$. Arra is rámutattak, hogy a magasabb iskolai végzettség (főként férfiaknál), valamint a vallásosság is számos kutatásban összefügg a véradási hajlandósággal (Piersma et al. 2017). A

\footnotetext{
${ }^{10}$ Bár meg kell jegyeznünk, hogy szerencsére a 18-25 éves korosztály véradó hajlandósága kiemelkedően magas, feltételezhetően részben a felsőoktatási véradóverseny hatására (Közlés: OVSz)

11 Természetesen a sokszoros véradók motivációjának megőrzése mellett. Hazánkban az évi legalább hérom véradás jóval nagyobb arányban jellemző a 35+ korosztályra, mint az attól fiatalabbakra (Nagy 2022)

12 Ez természetesen részben a szabályozásra is vezethető vissza, hiszen hazánkban is a nők 3-4 alkalommal, a férfiak pedig öt alkalommal adhatnak vért évente. (lásd: Véradásra való alkalmasság feltételei, ovsz.hu)
} 
véradók, főként a véradó központok könnyebb elérhetősége miatt nagyobb eséllyel érkeznek urbanizáltabb területekről, a családi állapot szempontjából pedig a házasság tekinthető prediktív tényezőnek (Wittock et al. 2017).

Minden társadalomban jóval több biológiai értelemben alkalmas személy van, mint ahányan ténylegesen részt vesznek donációban, Abásolo és Tsuchiya (2014) spanyol nagymintás vizsgálata szerint például a véradásra biológiai értelemben alkalmas személyeknél 67 százalék a valószínúsége annak, hogy nem ad majd vért életében ${ }^{13}$. Ugyanakkor egy világjárvány idején olyan emberek is erőteljes félelmi reakciókat mutatnak, akik amúgy egészségesek és véradásra alkalmasak $^{14}$ (Barnes et al. 2022; Sahu et al. 2020), ezáltal komoly kihívás elé helyezve a traszfúziológiai ellátórendszert és a toborzásban aktív szervezeteket.

\section{TÖRTÉNT AZ ÖNKÉNTES VÉRADÁSSAL A COVID-19 VILÁGJÁRVÁNY IDEJÉN?}

Gammon et al. (2020) szerint a SARS COV-2 pandémia kitörésével, majd eszkalálódásával, és

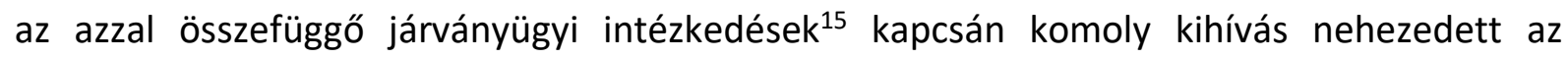
egészségügyi ellátórendszerre ${ }^{16}$, melynek következtében világszerte lecsökkent a véradó események száma (pl. munkahelyi, iskolai véradó helyszínek kiesése miatt). Nehézséget jelentett, hogy a mútétek elmaradása, valamint a COVID-19 megbetegedés megjelenése a véradók között folyamatos újratervezést igényelt a vérkészítmények kereslet-kínálata vonatkozásában ${ }^{17}$ (Barriteau et al 2020). A COVID-19 járvány kitörése utáni első hónapok vizsgálata kimutatta, hogy bár a véradás során a fertőzésveszély viszonylag alacsony volt, azon donorok, akik magas fertőzésveszélyre számítottak, sokkal kisebb valószínűséggel adtak vért. Továbbá azok is, akik betartották a COVID-irányelveket, ugyancsak kisebb valószínűséggel adtak vért (Chandler et al.2021).

\footnotetext{
${ }^{13}$ Ennek kapcsán említik a szerzők a potyautas hatást azokra, akik biológiai értelemben alkalmasak a véradásra, tehát egyetlen kizáró tényező sem áll fenn náluk, mégsem adnak, miközben bármikor rászorulhatnak az időközben közjóvá váló vérkészletre

${ }^{14}$ Bár a WHO 2003-ban kijelentette, hogy a SARS CoV - akkori tudásunk szerint - elméletileg nem terjed vértranszfúzióval, az új típusú koronavírus esetén ennek esélye eleinte nem volt teljesen kizárható.

${ }^{15}$ Ideiglenesen a véradástól eltiltották azokat, akik esetében felmerült a gyanú, hogy az új típusú koronavírussal fertőződtek az elmúlt időszakban (Pál et al. 2021: 1719)

${ }^{16} \mathrm{Ez}$ a rendszer biztosítja az elektív és sürgősségi sebészeti ellátáshoz szükséges vérkészítményeket az egészségügyi intézmények egységei ( $p l$. szülészetek, onkológiai szolgálatatások) számára

${ }^{17} \mathrm{~A}$ kórházba felvett COVID-19 betegek 13,4 százalékának volt szüksége vérátömlesztésre, ami alacsonyabb volt, mint a nem COVID-19 betegek száma. Továbbá a vörösvérsejtek jelentek meg a leggyakrabban transzfundált vérkészítményként (11,1 százalék).
} 
Mind hazai, mind nemzetközi viszonylatban elmondható, hogy hatékony toborzásra és a véradó központok személyzetének megfeszített munkájára volt szükség ahhoz, hogy e kihívásteli helyzetben is megmaradjon a többszörös véradók donációs hajlandósága, és továbbra is bevonásra kerüljenek új donorok a rendszerbe ${ }^{18}$. Hazánkban közel évi 50 ezerrel kevesebb egység vér került levételre 2020-ban (329 192 egység) és 2021-ben (332 970 egység) is, mint a COVID-19 járványt megelőző időszakban ${ }^{19}$. A vérfelhasználás csökkenése ${ }^{20}$, valamint egészségügyi dolgozók és a véradással foglalkozó szervezetek megfeszített munkája ${ }^{21}$ nyomán nem alakult ki vérellátás biztonságát veszélyeztető helyzet, mindössze a vérkészítmények átmeneti csökkenése fordult elő (Tordai et al. 2020). A pandémia idején a véradóknál is erős volt a bizonytalanság, a véradók egy része - dacára a biztonsági intézkedéseknek aggodalmat, zavart érzett, vagy esetleg téves hiedelme volt a COVID-19 járvány alatti véradás hatásaival kapcsolatban (Raturi - Kusum 2020; Sahu et al. 2020) és negatívan érintette őket a véradó központok ideiglenes elérhetetlensége (Barnes et al. 2022). Weidman et al. (2021) felmérése szerint a donorok többsége elégedett volt legutóbbi véradásával, és biztonságban érezte magát a véradás során. Néhány donor azonban több információt szeretett volna a világjárvány kezeléséről (20,3 százalék). A jövőbeli véradásra irányuló szándék szoros összefüggésben állt a véradással való általános elégedettséggel és a véradás alatti biztonságérzettel.

\section{A KUTATÁS CÉLJAI ÉS FŐBB KÉRDÉSFELTEVÉSEI}

Kutatásunk elsődleges kérdése az volt, hogy a COVID-19 járvány idején aktív donorok milyen szociodemográfiai mutatókkal (nem, életkor, iskolai végzettség, családi állapot, vallásosság) rendelkeztek, mekkora hányaduk végzett a véradáson kívül is proszociális cselekedeteket (saját és ismerősi körben), milyen mértékben érintette őket gazdasági és egészségügyi értelemben a pandémia. Emellett rákérdeztünk a félelmek (például megfertőződés,

\footnotetext{
${ }^{18}$ Ez csak hazánkban évente kb. 40 ezer új véradót jelent (Nagy 2022; személyes közlés)

${ }^{19}$ Dr. Nagy Sándor (Országos Vérellátó Szolgálat) szíves közlése alapján. 2017-ben 383638 egység, 2018-ban 382914 egység, 2019-ben pedig 376774 egység vér került levételre.

${ }^{20}$ A vörösvérsejt-, illetve plazmakészítmények felhasználása mintegy 30 százalékos, míg a thrombocyta készítményeké mintegy 20 százalékot csökkent 2020. április hónapban az előző év azonos időszakához képest (Tordai et al. 2020: 96)

${ }^{21}$ Miután a mobil véradási eseményeket (ahol az összes véradás 75 százaléka történik) már a COVID első időszakában naponta mondták le a szervezők (pl. munkahelyek), az OVSZ megnövelte az állandó vérgyújtési helyszínek számát (OVSz közlés 2020)
} 
biztonságosság hiánya, kevesebb véradó helyszín) és akadályok (úgy mint: bezártság, stresszszint megnövekedése, több mellékhatás) jelenlétére is a COVID járvány időszakában.

Kutatásunk másik kérdésfeltevése az volt, hogy hazai mintán is valid mérőeszköznek bizonyulnak-e a motivációs háttérváltozók mérésére - külföldön már előszeretettel - használt mérőeszközök (lásd. Ferguson et al. 2018). E tekintetben a vizsgálat úttörő jellegúnek tekinthető, mivel az említett tényezőket még ilyen formában nem vizsgálták Magyarországon.

\section{A KUTATÁSI MÓDSZER ÉS MINTA}

Kutatásunk adatfelvétele online és papír alapon valósult meg 2021 augusztusa és decembere között. Elsőként a közösségi média véradással foglalkozó többezer fős csoportjaiban (Véradók, Magyar Vöröskereszt stb.) került megosztásra az Unipoll kérdőívszerkesztő programmal készített kérdőív linkje, azonban ezen a platformon mindössze 72 fő töltötte ki azt, így indokolttá vált a papír-ceruza alapú adatfelvétel párhuzamos elindítása is. A Magyar Vöröskereszt ${ }^{22}$ segítségével a kérdőívek eljutottak a megyei központokba, akik azokat véradásaikon kitöltették, majd visszaküldték, így lehetővé téve egy demográfiai, életkori és véradások számát tekintve egyaránt heterogén minta bevonását.

Papír alapon 205 db kitöltött kérdőív érkezett vissza, a hiányosan kitöltött kérdőívek kizárása, valamint a tájékozott beleegyezések hiánya miatt $58 \mathrm{db}$ kérdőív kizárásra került. Így végül a hagyományos papír-ceruza és az online kitöltők száma összesen 219 fő (131 nő és 88 férfi), 18 és 68 éves kor közötti életkori megoszlással ( $M=43,51 ; S D=11,98)$, az ország 17 megyéjéből. Ez képezi tehát a teljes mintánkat ${ }^{23}$.

A donorok összes véradása 1 és 154 között mozgott ( $M=21,54, S D=23,3)$, a véradók közel felének (49,1 százalék) 1-13 közötti, 25-25 százalékának pedig 14-30 közötti, illetve több mint 30 véradása volt eddig. A COVID-19 járvány alatt az adatközlőink 0-9 alkalommal adtak vért $(M=2,45, S D=1,84)$. A minta leíró statisztikája az 1. táblázatban olvashatók részletesebben.

\footnotetext{
${ }^{22}$ Ezúton is köszönjük Váradi Mariann, Grubert Roland és Szepesi Ágnes, valamint a Magyar Vöröskereszt megyei és területi szervei dolgozóinak adatfelvétel terén nyújtott önzetlen segítségét, valamint a véradóknak a kitöltést. ${ }^{23}$ Köszönjük Kobolák Dóra adatbevitelben nyújtott segítségét.
} 
1. táblázat A minta szociodemográfiai háttere (N=219)

\begin{tabular}{|c|c|c|}
\hline & & $\begin{array}{l}\text { COVID-19 pandémia alatti } \\
\text { véradók mintája } \\
\mathrm{N}=219\end{array}$ \\
\hline \multirow[t]{2}{*}{ Nem } & férfi & 88 fö $(40,2 \%)$ \\
\hline & nő & 131 fö $(59,8 \%)$ \\
\hline & átlagéletkor & 43,51 év SD=11,98 \\
\hline \multirow[t]{5}{*}{ Családi állapot } & házas & 104 fő $(47,5 \%)$ \\
\hline & egyedülálló & 39 fö $(17,8 \%)$ \\
\hline & elvált vagy külön él & 16 fő $(7,3 \%)$ \\
\hline & párkapcsolatban él & 49 fó $(22,4 \%)$ \\
\hline & özvegy & 6 fö $(2,7 \%)$ \\
\hline \multirow{4}{*}{$\begin{array}{l}\text { A COVID } \\
\text { gazdasági } \\
\text { hatása a } \\
\text { személyre }\end{array}$} & csökkent az életszínvonala & 62 fő $(28,3 \%)$ \\
\hline & nőtt az életszínvonala & 4 fö $(1,8 \%)$ \\
\hline & nem változtak az anyagi körülményei & 128 fö $(58,4 \%)$ \\
\hline & nem szeretne válaszolni & 25 fő (11,5\%) \\
\hline \multirow[t]{4}{*}{ Lakóhely } & főváros & 30 fő $(13,7 \%)$ \\
\hline & megyeszékhely, megyei jogú város & 71 fö (32,4\%) \\
\hline & egyéb város & 65 fö $(29,7 \%)$ \\
\hline & község & 53 fö (24,2\%) \\
\hline \multirow[t]{9}{*}{ Végzettség } & 8 általános & 5 fö $(2,3 \%)$ \\
\hline & szakiskola, szakközépiskola, technikum & 56 fö $(25,6 \%)$ \\
\hline & gimnázium & 20 fö $(9,3 \%)$ \\
\hline & felsőoktatási szakképzés & 29 fö $(13,4 \%)$ \\
\hline & jelenleg felsőoktatásban tanul & 7 fö $(3,2 \%)$ \\
\hline & fóiskola & 43 fö (19,9\%) \\
\hline & $\mathrm{BA} / \mathrm{BSC}$ & 23 fő $(10,6 \%)$ \\
\hline & $\mathrm{MA} / \mathrm{MSc}$ & 29 fö $(13,4 \%)$ \\
\hline & posztgraduális & 4 fö $(1,9 \%)$ \\
\hline \multirow[t]{2}{*}{ Vallásos } & igen & 100 fő $(45,7 \%)$ \\
\hline & nem & 116 fő $(53,7 \%)$ \\
\hline
\end{tabular}

Forrás: saját szerkesztésű táblázat adatbázis alapján

A kérdőív hat fő kérdéscsoportból állt:

- Szociodemográfiai háttér

Rákérdeztünk a kitöltő nemére, életkorára, lakóhelyének típusára, családi állapotára, iskolai végzettségére, vallásosságára, valamint arra is, hogy jövedelmi viszonyait hogyan érintette a COVID-19 járvány.

- Proszociális aktivitás

Külön blokkban tértünk ki a személy életében megjelenő proszociális aktivitásokra (Ferguson et al. 2018). Megkérdeztük, hogy végzett-e már a személy önkéntes tevékenységet korábban 
(pl. idősotthon, gyermekotthon, kórház), adományozott-e pénzt vagy részt vett-e adománygyűjtésben. A bejelölt aktivitások száma alapján egy nominális változót hoztunk létre, ami 0-6 pont közötti értékkel jelezte a személy proszociális aktivitását. Ugyancsak kérdésként szerepelt, hogy a személy családtagjai részt vettek-e már proszociális tevékenységekben.

- Véradó aktivitás és a COVID-19 érintettség

Rákérdeztünk, hogy a személy adott-e teljes vért korábban, és ha igen, hány alkalommal eddig, és részt vett-e irányított véradásban. Felmértük, hogy a véradás, illetve a vérkészítményre szorulás (pl. vértranszfúzió) milyen mértékben fordult elő a személy környezetében (rokonok, barátok, családtagok) és hogy hány alkalommal adott vért a COVID-19 járvány kezdete (2020. március 12.) óta. A kérdések között szerepelt még, hogy egyéb vérkészítményt (vérplazma, vérlemezke) adott-e a személy a COVID-19 járvány előtt és után, valamint, volt-e a COVID-19 fertőzött, és ha igen, milyen súlyosságú tünetekkel. Bejelölhető volt, hogy emiatt hány napig esett ki a véradásból. Fontosnak tartottuk arra is rákérdezni, hogy a COVID19 járvány alatt hány olyan személy élt a háztartásában, aki erősen veszélyeztetett volt a betegség kapcsán (például időskorú, vagy alapbetegséggel rendelkezett).

- COVID-19 járvánnyal összefüggő aggodalmak, észlelt akadályok

Ebben a blokkban 8 itemet alkalmaztunk annak vizsgálatára, hogy a COVID milyen mértékü félelemmel (például: „Féltem attól, hogy a véradás helyszínén megfertőződöm COVID-dal”), és észlelt akadályokkal (pl. bezártság, személyes veszteségek, stressz-szint növekedése, általános aktivitás csökkenése) járt együtt. Ebből egy kumulált skálát hoztunk létre. A skála reliabilitás mutatója megfelelő $(\alpha=0,829)$.

- Morális felháborodás

A konstruktumot négy itemmel mértük, melyek a Deontikus Igazságosság Skála (Beugre 2012) részét képezik. Minden egyes itemre egy ötfokú skálán kellett válaszolni (ahol 1 = egyáltalán nem értek egyet, míg 5 = teljes mértékben egyetértek), a magas pontszámok az abbéli szomorúságra utaltak, amelyet a másokkal szembeni igazságtalan és méltánytalan bánásmód váltott ki a kitöltőből (Példa az itemekre: „Szomorú vagyok, amikor azt látom, hogy valakivel méltánytalanul bánnak"). A faktorstruktúra felmérésére statisztikai elemzéseket végeztünk. 
- Vonakodó altruizmus

Jelen vizsgálat céljából a korábbi vizsgálatok ide vonatkozó eredményeinek felhasználásával (például Ferguson et al. 2012; Ferguson et al. 2018) - a véradás kontextusára adaptálva - egy 9 itemből álló kérdőívet hoztunk létre, melyben egy ötfokú skálán (ahol 1=egyáltalán nem értek egyet, míg 5= teljes mértékben egyetértek) kellett jelölniük a személyeknek, milyen mértékben vált ki véradó aktivitást belőlük mások közönye, önzősége, segítő magatartásának elmaradása. Példa az itemekre: „Frusztrál, hogy sokan nem adnak vért”, „Úgy érzem, társadalmunk közönyössé vált a véradás iránt”. Mivel a 9. item „Sok ember csak vonakodva ad vért" nem mutatott magas illeszkedést a többivel, így azt kizártuk. A kérdőív pszichometriai mutatóinak vizsgálatára statisztikai elemzéseket alkalmaztunk.

A nyers adatokat Microsoft Excel adatfájlba rendeztük, majd pedig SPSS 23.0 statisztikai szoftverrel végeztük el a leíró és következtető statisztikákat (átlagok, szórások, korrelációk, tpróbák). A két motivációs háttérváltozót mérő skálán (morális felháborodás és vonakodó altruizmus) feltáró és megerősítő faktorelemzést végeztünk. Az elemzéshez a JASP statisztikai program 0.16-os verzióját használtuk (JASP Team, 2021), mely egy nyílt forráskódú szoftver. A faktorelemzéseket mindkét skálán promax forgatással végeztük, maximum likelihood becsléssel. A becslés hibáját robust (sandwich) módszerrel becsültük meg.

\section{A PROSZOCIÁLIS AKTIVITÁS ÉS A COVID-19 JÁRVÁNYBAN VALÓ ÉRINTETTSÉG}

Eredményeink egyrészt arra mutatnak rá, hogy a véradók jelentős része rendelkezik karitatív cselekedetekben részt vevő ismerősökkel, rokonokkal (minden ismerősi kategóriában a véradók legalább ötöde rendelkezik véradó ismerőssel is), illetve, hogy saját maguk is végeztek az önkéntességen kívül más proszociális cselekedeteket is, ami főként az adományozásra és egyes önkéntes tevékenységekre terjed ki. A kutatásban résztvevő véradók 77,6 százaléka nem volt COVID-19 fertőzött, vagy nem tud róla, 14,2 százaléka enyhe, 5,5 százaléka pedig közepes tünetekkel esett át a fertőzésen (2. táblázat), átlagosan 27,5 napig nem adhattak emiatt vért a fertőzésen átesett donorok. Amint láthatjuk, a minta megközelítőleg 23 százaléka nem volt fertőzött, így a COVID érintettség véradásokra gyakorolt hatásait nem volt lehetőségünk arányos részmintákon összehasonlítani. Az egyszempontos varianciaanalízis alapján azonban láthatjuk, hogy a COVID alatti véradások számát tekintve nincs szignifikáns különbség ( $F=2,047 p=0,132)$ a csoportok között: a fertőzésen enyhe tünetekkel átesők 
adtak a legtöbbször vért $(M=2,86$ SD $=1,76)$, akiket a COVID fertőzésen nem átesettek követtek ( $M=2,43 S D=1,85)$, végül a közepes tünetekkel átesők $(M=1,58 S D=1,68)$ szignifikánsan kevesebbszer adtak ebben az időszakban, mint az enyhe tünetekkel átesők ( $\mathrm{t}$ = $2,128 p<0,05 r=0,32)$.

2. táblázat A minta proszociális aktivitásainak és COVID-19 járványban való érintettségének jellemzői $(N=219)$

\begin{tabular}{|c|c|c|}
\hline & & $\begin{array}{l}\text { COVID-19 pandémia alatti } \\
\text { véradók mintája } \\
\mathrm{N}=219\end{array}$ \\
\hline \multirow{2}{*}{$\begin{array}{l}\text { Irányított véradásban } \\
\text { részvétel }\end{array}$} & igen & 122 fő $(55,7 \%)$ \\
\hline & nem & 95 fö (43,4\%) \\
\hline \multirow{5}{*}{$\begin{array}{c}\text { Részt vett-e valaha az alábbi } \\
\text { segítségnyújtó } \\
\text { aktivitásokban (igen \%) }\end{array}$} & adománygyűjtésben & 122 fő $(55,7 \%)$ \\
\hline & idősek otthonában önkéntesség & 14 fö $(6,4 \%)$ \\
\hline & gyermekotthonban önkéntesség & 33 fő $(15,1 \%)$ \\
\hline & adományozott pénzt & 154 fő $(70,3 \%)$ \\
\hline & kórházi önkéntesség & 12 fő $(5,5 \%)$ \\
\hline \multirow{3}{*}{$\begin{array}{l}\text { Családtagok részvétele } \\
\text { karitatív tevékenységben }\end{array}$} & igen & 65 fö (29,7\%) \\
\hline & nem & 104 fő $(47,5 \%)$ \\
\hline & nem tudja & 48 fö (21,9\%) \\
\hline \multirow{6}{*}{$\begin{array}{l}\text { Véradás a legközelebbi } \\
\text { rokoni és ismerősi körben } \\
\text { (igen\%) }\end{array}$} & édesanya & 62 fö (28,3\%) \\
\hline & édesapa & 81 fö (36,5\%) \\
\hline & testvér & 85 fö $(38,5 \%)$ \\
\hline & nagybácsi/nagynéni & 46 fö (21\%) \\
\hline & unokatestvér & 71 fő $(32,4 \%)$ \\
\hline & barát és egyéb ismerős & 184 fő (84\%) \\
\hline \multirow{2}{*}{ Vérátömlesztésen esett-e át } & a kitöltő (igen\%) & 17 fö $(7,8 \%)$ \\
\hline & hozzá közelálló személy (igen\%) & 63 fö (28,8\%) \\
\hline \multirow{3}{*}{ Esett-e át COVID fertőzésen } & nem voltam/nem tudok róla & 170 fő $(77,6 \%)$ \\
\hline & átestem enyhe tünetekkel & 31 fő $(14,2 \%)$ \\
\hline & átestem közepes tünetekkel & 12 fő $(5,5 \%)$ \\
\hline
\end{tabular}

Forrás: saját szerkesztésű táblázat adatbázis alapján

\section{A COVID-19 JÁRVÁNY ALATT ÉSZLELT AKADÁLYOK ÉS A VÉRADÁSOK ÖSSZEFÜGGÉSEI}

A COVID-19 járvány alatti észlelt akadályok közül a teljes mintán legmeghatározóbb kettő a COVID alatti megnövekedett stressz-szint $(M=2,23 ; S D=1,34)$ és a csökkent aktivitási szint $(M=2,33 ; S D=1,4)$, amelyet a pandémia alatti személyes veszteségek $(M=1,92 ; S D=1,39)$ követtek. Mint láthatjuk, egyik akadály sem volt kiemelkedően magas, de jelen voltak a véradóink életében. A 8 itemből képzett összpontszám és a COVID-19 járvány alatti véradások 
száma között gyenge negatív összefüggést mutattunk ki ( $r=-0,159 ; p<0,05)$. Ha ugyanezt itemenkénti részletességgel is megvizsgáljuk, arra jutunk, hogy nincs összefüggés a COVID-19 járvány alatti megnövekedett stressz-szint, a pandémia alatti személyes veszteségek, az általános aktivitási szint csökkenése, a véradó helyszínek nehezebb megtalálása és a pandémia alatti több mellékhatás észlelése, valamint a véradások száma között. Pozitívan függ össze ugyanakkor a járvány alatti véradások száma az eddigi véradások számával $(r=0,427 ; p<0,01)$, negatívan az attól való félelemmel, hogy a véradás helyszínén megfertőződik a vírussal ( $r$ = 0,152; $p<0,05)$, az azzal való egyetértéssel, hogy a pandémia alatti bezártság akadályt jelentett a véradásban $(r=-0,154 ; p<0,05)$, valamint az azzal való egyetértéssel is, hogy kevés tudásunk van még a vírusról ahhoz, hogy biztonságosnak érezze a véradást $(r=-0,207 ; p<$ 0,01). A kérdőívben szereplő állítások a 3. táblázatban olvashatók.

3. táblázat: A COVID-19 járvány alatti észlelt akadályok mérésére szolgáló itemek

\begin{tabular}{|c|}
\hline Item \\
\hline Féltem attól, hogy a véradás helyszínén megfertőződöm COVID-dal \\
\hline A COVID időszak alatti bezártság akadályt jelentett a véradásban. \\
\hline A COVID időszakban úgy éreztem, keveset tudunk még a betegségről ahhoz, hogy biztonságosnak \\
érezzem a véradást \\
\hline A COVID alatt megnövekedett az általános stressz-szintem \\
\hline A COVID alatt személyes veszteségek értek (pl. fontos személy elvesztése) \\
\hline A COVID alatt csökkent az általános aktivitási szintem. \\
\hline A COVID időszakban nehezebben találtam megfelelő véradó helyszínt, mint előtte. \\
\hline A COVID időszakban több mellékhatással szembesülök véradás után, mint a járvány előtti \\
véradásoknál.
\end{tabular}

\section{A MORÁLIS FELHÁBORODÁS SKÁLA PSZICHOMETRIAI MUTATÓINAK FELTÁRÁSA}

A Morális Felháborodás Skálán feltáró és megerősítő faktorelemzést végeztünk. A feltáró faktorelemzés során az előfeltételei teljesültek, a KMO érték 0,823 volt, a Bartlett teszt szignifikáns volt $(p<0,001)$. A faktorok számának megállapításához a Kaiser kritériumot használtuk, ez alapján egy faktor rendelkezett 1 fölötti sajátértékkel. Az illeszkedési mutatók közül a TLI érték 0,965 volt, amely jó illeszkedést mutat, azonban az RMSEA érték 0,147 volt, mely gyenge illeszkedést mutat. Az összes tétel egyenesen töltött a megállapított faktorra, a faktortöltéseket a 4. táblázat mutatja. 
4. táblázat: A Morális Felháborodás Skála faktortöltései

\begin{tabular}{|c|c|}
\hline Item & Faktortöltés \\
\hline Szomorú vagyok, amikor azt látom, hogy valakivel méltánytalanul bánnak. & 0,878 \\
\hline Zavar, amikor azt látom, hogy másokkal igazságtalanul bánnak. & 0,939 \\
\hline A másokkal szembeni igazságtalan bánásmód elszomorít. & 0,965 \\
\hline A másokkal szembeni igazságtalan bánásmód megérint érzelmileg. & 0,732 \\
\hline
\end{tabular}

A megerősitő faktorelemzés során a khi négyzet teszt szignifikáns volt $(\chi 2(2)=10,49, p=$ 0,005), amely a nagy elemszámnak tudható be (Bentler - Bonnet 1980; Jöreskog - Sörbom 1993). A relatív illeszkedési mutatók jó illeszkedést mutattak ( $C F I=0,990, T L I=0,969)$, az SRMR értéke megfelelő (SRMR =0,011) volt. Az RMSEA értéke 0,139 volt, meglehetősen nagy konfidencia intervallummal ( $\mathrm{Cl}$ alsó $=0,065, \mathrm{Cl}$ felső $=0,227$ ), mely gyenge illeszkedést mutat. A reliabilitás vizsgálata során a Cronbach alfa érték 0,92 volt. Az átlagos interitem korreláció magas volt (0,769 értékkel), az átlagpontszám a skálán 18,23 volt $(S D=2,84)$ a maximum elérhető 20 pontból, amely alapján a válaszadók meglehetősen magas pontszámokat adtak a kérdőív kérdéseire.

Fontos azonban szem elótt tartanunk, hogy a kérdőiv általános morális felháborodást mér, a mintát azonban olyan véradók alkották, akik a pandémiás időszakban is adnak vért, így feltételezhetô, hogy ez a véradó populáció az átlag véradónál is magasabb morális felháborodással rendelkezik.

Érdemes egy pillantást vetnünk a morális felháborodás és a véradások száma közötti összefüggésre. Pearson korrelációt vizsgálva nem találunk összefüggést sem az összes véradások, sem a COVID alatti véradások és a morális felháborodás között, tehát nem igaz az az összefüggés, hogy minél többszörös véradó valaki, annál erősebb a morális felháborodása, inkább azt láthatjuk, hogy a véradó mintán egységesen magas. A morális felháborodás gyenge pozitív összefüggést mutat az egyéb végzett proszociális aktivitások számával $(r=0,165 ; p<$ $0,05)$, valamint, azzal, hogy az illető tervezi, hogy a következő 6 hónapban adjon vért $(r=0,155$; $p<0,05)$. A nemi különbségek kapcsán a nők magasabb morális felháborodása volt kimutatható $(t=3,662 p<0,01 r=0,24)$. 


\section{A VONAKODÓ ALTRUIZMUS SKÁLA VÉRADÓKRA KIALAKÍTOTT VÁLTOZATÁNAK}

\section{PSZICHOMETRIAI VIZSGÁLATA}

A Vonakodó Altruizmus Skála magyar, rövidített véradó populációra kialakított változatán feltáró és megerősítő faktorelemzést végeztünk. $A K M O$ érték $(K M O=0,872)$ és Bartlett teszt eredménye $(p<0,001)$ alapján az elemzés elvégezhető volt. A faktorok számának meghatározásához használt Kaiser kritérium alapján egy faktor került megállapításra, fordított tétel nélkül. Az illeszkedési mutatók nem mutattak megfelelő illeszkedést (RMSEA $=0,156, T L I$ $=0,789$ ).

$A z$ alacsony illeszkedés okának feltérképezéséhez a megerősítő faktorelemzés során a modifikáció indexek alapján tájékozódtunk, mely alapján a 9-es tétel („Sok ember vonakodva ad csak vért”) kivételre került. Így az illeszkedési mutatók a következőképpen alakultak: Х2(20) $=99,576 \mathrm{p}<0,001, \mathrm{CFI}=0,902, \mathrm{TLI}=0,862, \mathrm{SRMR}=0,068, \mathrm{RMSEA}=0,135(\mathrm{Cl}$ alsó $=0,110, \mathrm{Cl}$ felső $=0,160)$. Ezek alapján, az RMSEA kivételével az illeszkedési mutatók jó illeszkedést mutatnak. A végleges faktortöltések az 5 . táblázatban találhatók.

5. táblázat: A Vonakodó Altruizmus Skála faktortöltései

\begin{tabular}{|c|c|}
\hline Item & Faktortöltés \\
\hline Nem bízok abban, hogy mások adnak majd. & 0,404 \\
\hline Nagyon kevés ember ad vért manapság. & 0,495 \\
\hline Frusztrál, hogy sokan nem adnak vért. & 0,790 \\
\hline Dühös vagyok, mert sokan nem adnak vért. & 0,863 \\
\hline Szégyellem, hogy sokan nem adnak vért & 0,826 \\
\hline Mások vérkészítményre szorulók iránti közönye feldühít. & 0,712 \\
\hline Szomorú vagyok, hogy mások általában nem adnak vért. & 0,693 \\
\hline Úgy érzem, társadalmunk közönyössé vált a véradás iránt & 0,585 \\
\hline
\end{tabular}

A kérdőív Cronbach alfa értéke 0,87 volt, az átlagos interitem korreláció 0,46 . A kérdőív átlagpontszáma 22,47 volt (SD = 7,22, a minimálisan elérhető pontszám 8 és 40 pont közötti). A vonakodó altruizmus nem mutat szignifikáns összefüggést a COVID alatti véradások számával, az egyéb végzett proszociális aktivitások számával, valamint a nemek között sem találunk szignifikáns különbséget a jelenség kapcsán. Ugyanakkor gyenge pozitív összefüggést azzal, hogy az illető tervezi, hogy a következő 6 hónapban adjon vért $(r=0,150 ; p<0,05)$. 


\section{ÖSSZEGZÉS}

Vizsgálataink egy irányba mutatnak Alfieri et al. (2017) eredményeivel, akik szerint a véradók többsége a véradáson kívül egyéb proszociális aktivitásokban is elkötelezett. Feltehetően társadalmi nyitottságuk és magas morális érzékenységük okán (lásd. morális felháborodás magas jelenléte) más társadalmi ügyek (például környezetvédelem, esélyegyenlőség) iránt is nagyobb fogékonyságot mutatnak, ezen összefüggés vizsgálata további jövőbeli kutatások alapját képezheti. Rámutattunk, hogy a morális felháborodás skála jól alkalmazható véradó mintán, azonban az illeszkedés hiányosságai véleményünk szerint a specifikus mintával magyarázhatóak. Mivel növekvő számú kutatás (Evans - Ferguson 2014) szerint a véradókra alapvetően is magasabb morális felháborodás jellemző, emellett a pandémiás időszak alatt a véradóknál feltehetően alapvetően is magasabb morális felháborodás várható, ezért szükséges diverzebb önkéntes mintán is megvizsgálni a skála mutatóit. A vonakodó altruizmus skála ugyancsak alkalmazhatónak tûnik, azonban a konstruktum a véradók egészére nézve kisebb jelentőségű. Így a nemzetközi kutatásokkal összhangban érdemes lenne mélyebben megvizsgálni, hogy milyen jellemzőkkel (például véradó karrier különböző állomásaival) leírható donorok számára kiemelt jelentőségű - motivációs értelemben - a vonakodó altruizmus. A pandémiás helyzet jelentősége itt is kiemelhető, a véradó kommunikációs felhívásokban is fontos felhívó jelleggel bíró üzenet lehet a vonakodó altruisták megszólítása („mások nem adnak elég vért, így Önre is szükségünk van”).

Egyetértve Chandler és munkatársai (2021) konklúziójával, javasoljuk, hogy a véradó szervezetek fontolják meg olyan speciális kampányok indítását, amelyek a válság idején a donorok altruista motivációjára összpontosítanak, ugyanakkor azok számára pedig érdemes eltérő üzeneteket megfogalmazni, akiket a másokkal való méltánytalan vagy igazságtalan bánásmód, vagy a potyautas hatás (kihasználja mások segítségét, de ő nem segít) motivál cselekvésre. Ilyen fajta motivációs háttér szerint szegmentált, többkomponensű marketing kommunikáció a véradók jóval szélesebb spektrumát lenne képes megszólítani. Ugyancsak érdemes hangsúlyozni a véradók számára, hogy a véradás során a fertőzéstől való félelem csökkentését célzó biztonsági intézkedések betartása fontos, valamint kiemelni azt is, hogy nem lehetséges a COVID-19 donációval történő átadása (Masser et al 2020). Hazánkban pl. az 
OVSz is felismerte, hogy a fertőzéstől való félelem negatív hatású, így a véradóknak ${ }^{24}$ és a munkahelyeknek ${ }^{25}$ szóló tájékoztatóiban is felhívta erre a figyelmet.

\section{IRODALOM}

3/2005 EüM az emberi vér és vérkomponensek gyüjtésére, vizsgálatára, feldolgozására, tárolására és elosztására vonatkozó minőségi és biztonsági előírásokról, valamint ezek egyes technikai követelményeiről. Letöltés 2021.12.12. https://net.jogtar.hu/jogszabaly?docid=a0500003.eum

2005. évi LXXXVIII. törvény a közérdekű önkéntes tevékenységről. Letöltés dátuma: 2021.12.12. https://net.jogtar.hu/jogszabaly?docid=a0500088.tv

Abásolo, Ignacio - Tsuchiya, Aki (2014): Blood donation as a public good: an empirical investigation of the free rider problem. The European Journal of Health Economics, 15(3) pp. 313-321.

Alfieri, Sará - Pozzi, Maura - Marta, Elena - Saturni, Vincenzo - Aresi, Giovanni - Guiddi, Paolo. (2017): "Just" blood donors? A study on the multiaffiliations of blood donors. Transfusion and Apheresis Science, 56(4) pp. 578-584.

Andreoni, James (1990): Impure altruism and donations to public goods: A theory of warm-glow giving. The Economic Journal, 100(401) pp. 464-477.

Barnes, Linda S. - Al-Riyami Arwa Z - Ipe, Tina S. - Bloch, Evan M. - Sibinga Cees Smit -Eichbaum, Quentin G. (2022): COVID-19 and the impact on blood availability and transfusion practices in low- and middle-income countries. Transfusion pp.1-10.

Bednall, Timothy C., - Bove, Liliana. L. (2011): Donating blood: a meta-analytic review of self-reported motivators and deterrents. Transfusion Medicine Reviews, 25(4) pp. 317-334.

Béla-Csovcsics Andrea - Kincsesné Vajda Beáta (2018): Véradó vagyok. De miért? Egyetemisták véradási szokásait befolyásoló pszichológiai és személyes tényezők vizsgálata. Marketing \& Menedzsment, 52(3-4) pp. 61-71.

Beugre, Constant D. (2012): Development and validation of a Deontic Justice Scale. Journal of Applied Social Psychology, 42. pp. 2163-2190.

Béla-Csovcsics Andrea - Kincsesné Vajda Beáta (2018): Véradó vagyok. De miért? Egyetemisták véradási szokásait befolyásoló pszichológiai és személyes tényezők vizsgálata. Marketing \& Menedzsment, 52(3-4) pp. 61-71.

Bentler, Peter M. - Bonnet, Douglas C. (1980): Significance Tests and Goodness of Fit in the Analysis of Covariance Structures. Psychological Bulletin, 88(3) pp. 588-606.

Carpenter, Jeffrey - Myers, Caitlin Knowles (2010): Why volunteer? Evidence on the role of altruism, image, and incentives. Journal of Public Economics, 94(11-12), pp. 911-920.

Chandler, Torsten - Neumann-Böhme, Sebastian - Sabat, Iryna - Barros, Pedro Pita - Brouwer, Werner - van Exel, Job - Schreyögg, Jonas - Torbica, Aleksandra - Stargardt, Tom (2021): Blood donation in times of crisis: Early insight into the impact of COVID-19 on blood donors and their motivation to donate across European countries. Vox Sanguinis 116, pp. 1031-1041.

\footnotetext{
${ }^{24}$ https://www.ovsz.hu/ovsz/veradoknak-szolo-tajekoztatas

25 https://www.ovsz.hu/munkahelyeknek-szolo-tajekoztatas
} 
Csaba Sára - Belinszky Anna - Lukács Zsófia Anna - Lantos Nóra Anna - Kende Anna (2017): Menekültek Magyarországon: a politikai attitűdök és a morális felelősségvállalás szerepe a kollektív cselekvésben. Alkalmazott Pszichológia, 17(2) pp. 29-49.

Dorner László (2020): Az önkéntesség lélektani vonatkozásainak empirikus vizsgálatai. Doktori disszertáció, Debreceni Egyetem Humán Tudományok Doktori Iskola.

Evans, Ronald - Ferguson, Eamonn (2014): Defining and measuring blood donor altruism: a theoretical approach from biology, economics and psychology. Vox Sanguinis, 106(2) pp. 118-126.

Ferguson, Eamonn (2015): Mechanism of altruism approach to blood donor recruitment and retention: a review and future directions. Transfusion Medicine, 25(4) pp. 211-226.

Ferguson, Eamonn (2022): What blood and organ donation can tell us about cooperation? Current Opinion in Psychology, 44. pp. 202-207.

Ferguson, Eamonn - Atsma, Femke - De Kort, Wim -Veldhuizen, Ingrid (2012): Exploring the pattern of blood donor beliefs in first-time, novice, and experienced donors: differentiating reluctant altruism, pure altruism, impure altruism, and warm glow. Transfusion, 52(2) pp. 343-355.

Eamonn, Ferguson - Dorner, László - France, Cristopher. R. - France, Janis. L. - Masser, Barbara - Lam, Michael - Marta, Elena - Alfieri, Sara - Adams, Byron - in 't Veld, Elisabeth Huis - Scerri, Josianne. (2018): Blood donor behaviour, motivations and the need for a systematic cross-cultural perspective: the example of moral outrage and health-and non-health-based philanthropy across seven countries. ISBT Science Series, 13(4) pp. 375-383.

Ferguson, Eamonn - Lawrence, Claire (2018): It is only fair: blood donors are more sensitive to violations of fairness norms than nondonors-converging psychometric and ultimatum game evidence. Vox Sanguinis, 113(3) pp. 242-250.

Gammon, Richard R. - Prichard, Alicia Bellido - Gannett, Michael Sel - Yordanov, Boyan (2021): The effect of COVID-19 on blood donation habits. Transfusion, 61(4) pp. 1134-1140.

Healy, Kieran (2010): Last best gifts. University of Chicago Press.

JASP Team (2021): JASP (Version 0.16)[Computer software].

Jöreskog, Karl - Sörbom, Dag (1993): LISREL 8: Structural Equation Modeling with the SIMPLIS Command Language. Chicago, IL: Scientific Software International Inc.

Lotz, Sebastian - Okimoto, Tyler G. - Schlösser, Thomas - Fetchenhauer, Detlef (2011): Punitive versus compensatory reactions to injustice: Emotional antecedents to third-party interventions. Journal of Experimental Social Psychology, 47(2) pp. 477-480.

Lyle III, Henry F. - Smith, Eric A. - Sullivan, Roger J. (2009): Blood donations as costly signals of donor quality. Journal of Evolutionary Psychology, 7(4) pp. 263-286.

Masser, Barbara. M - Hyde, Melissa K. - Ferguson, Eamonn (2020): Exploring predictors of Australian community members' blood donation intentions and blood donation-related behavior during the COVID-19 pandemic. Transfusion, 60(12) pp. 2907-2917.

Montada, Leo-Schneider, Angela (1989): Justice and emotional reactions to the disadvantaged. Social Justice Research, 3(4) pp. 313-344.

Nagy Sándor (2022): A véradások száma 2017-2021 között hazánkban. Személyes közlés az Országos Vérellátó Szolgálat hivatalos statisztikái nyomán.

OVSz. (é.n.): Miért fontos a véradás. Letöltés dátuma: 2021.12.20. https://www.ovsz.hu/hu/miert-fontos-veradas

OVSz (2020): Véradóknak szóló tájékoztatás. Letöltés dátuma: 2021.12.20. https://www.ovsz.hu/ovsz/veradoknak-szolo-tajekoztatas 
OVSz (2020): Munkahelyeknek szóló tájékoztatás. Letöltés dátuma: 2021.12.20. https://www.ovsz.hu/hu/munkahelyeknek-szolo-tajekoztatas

Pál Sándor - Réger Barbara - Kiss Tamás - Hussain Alizedeh - Vereczkei András - Miseta Attila Szomor Árpád - Faust Zsuzsanna (2021): A SARS-CoV-2-pandémia hatása a vérkészítményfelhasználásra a Pécsi Tudományegyetemen. Orvosi Hetilap, 162(43) pp. 1718-1724.

Piersma, Tjeerd W. - Bekkers, René - Klinkenberg, Elisabeth. F. - De Kort, Wim. L. - Merz, Eva-Maria (2017): Individual, contextual and network characteristics of blood donors and non-donors: a systematic review of recent literature. Blood Transfusion, 15(5) pp. 382.

Raturi Manish - Kusum Anuradha (2020): The blood supply management amid the COVID-19 outbreak. Transfusion Clinique et Biologique, 27(3) pp. 147-151.

Roberts, Nicholas - James, Spencer - Delaney, Meghan - Fitzmaurice, Christina (2019). The global need and availability of blood products: a modelling study. The Lancet Haematology, 6(12), 606-615.

Sahu, Kamal Kant - Raturi, Manish - Siddiqui, Ahmad Daniyal - Cerny, Jan (2020): "Because every drop counts": blood donation during the COVID-19 pandemic. Transfusion Clinique et Biologique, 27(3) pp. 105-108.

Shan Hua - Zhang Ping (2004): Viral attacks on the blood supply: the impact of severe acute respiratory syndrome in Beijing. Transfusion, 44(4) pp. 467-469

Steinberg, David (2010): Altruism in medicine: Its definition, nature and dilemmas. Cambridge Quarterly of Healthcare Ethics, 19. pp. 249-257.

Thulin, Erik W. - Bicchieri, Cristina (2016): I'm so angry I could help you: Moral outrage as a driver of victim compensation. Social Philosophy and Policy, 32(2) pp. 146-160.

Titmuss, Richard. M. (1970): The gift relationship. From human blood to social policy. The gift relationship. London: Allen and Unwin.

Tordai Attila - Nagy Sándor - Baróti-Tóth Klára - Marton Imelda - Lázár Mária - Demeter Judit - Masszi Tamás - Matusovits Andrea (2020): A SARS-CoV2-járvány hatása a hazai vérellátásra. HematológiaTranszfuziológia, 53. pp. 96-105

Van de Vyver, Julie - Abrams, Dominic (2015): Testing the prosocial effectiveness of the prototypical moral emotions: Elevation increases benevolent behaviors and outrage increases justice behaviors. Journal of Experimental Social Psychology, 58. 23-33.

Van Doorn, Janne - Zeelenberg, Marcel - Breugelmans, Seger M. (2014): Anger and prosocial behavior. Emotion Review, 6(3) pp. 261-268.

Weidmann, Christian - Derstroff, Marie - Klüter, Harald - Oesterer, Martin - Müller-Steinhardt, Michael (2021): Motivation, blood donor satisfaction and intention to return during the COVID-19 pandemic. Vox Sanguinis, 2021, pp. 1-7.

Wittock, Nathan - Hustinx, Lesley - Bracke, Piet - Buffel, Veerle (2017): Who donates? Cross-country and periodical variation in blood donor demographics in Europe between 1994 and 2014, Transfusion, 57. pp. 2619-28

World Health Organization (2003): WHO recommendations on SARS and blood safety. Letöltés dátuma:

2021.12.05.

https://www.who.int/publications/m/item/who-recommendations-on-sars-and-blood-safety

World Health Organization (2020): Blood safety and availability. Letöltés dátuma: 2021.12.20. https://www.who.int/news-room/fact-sheets/detail/blood-safety-and-availability

Zeger, Gary - Selogie, Eileen - Shulman, Ira A. (2007). Blood donation and collection. Blood Banking and Transfusion Medicine, pp. 157-182. 